\title{
MYCOTOXIC AND ARISTOLOCHIC ACID THEORIES OF THE DEVELOPMENT OF ENDEMIC NEPHROPATHY
}

\author{
Maja PERAICA, Ana-Marija DOMIJAN, and Marko ŠARIĆ \\ Institute for Medical Research and Occupational Health, \\ Zagreb, Croatia \\ Received in November 2007 \\ Accepted in January 2008
}

\begin{abstract}
Despite many efforts of scientists and epidemiologists, the aetiology of endemic nephropathy (EN) is still unknown. This disease occurs in the rural population of geographically limited areas of Bulgaria, Bosnia and Herzegovina, Croatia, Romania, and Serbia, and a number of theories have been proposed about its aetiology. The mycotoxin theory has prevailed until now, based on the studies of nephrotoxic mycotoxin ochratoxin A (OTA) that revealed higher frequency of OTA-positive food and blood samples in endemic than in non-endemic areas.

However, a new aristolochic acid (AA) theory of EN origin has been proposed recently, due to the histological similarities in kidney lesions between patients suffering from EN and patients suffering from Chinese herbs nephropathy caused by AA. Until now it has not been unequivocally proved that the inhabitants of EN areas are exposed to higher concentration of AA than in other regions and the exposure pathways are rather uncertain.

This paper presents most important studies supporting both theories, indicating also the inconsistencies of each.
\end{abstract}

KEY WORDS: Chinese herbs nephropathy, DNA adducts, kidney tumours, mycotoxins, ochratoxin A, p53

Endemic nephropathy (EN) is a bilateral chronic kidney disease that occurs in the rural population of some areas of Bulgaria, Bosnia and Herzegovina, Croatia, Romania, and Serbia. This fatal disease is characterised by focused and limited geographical distribution, occurrence in farming households, and high mortality from uraemia. It is interesting that since the disease was discovered, the endemic areas are stable; there are no new endemic areas, and none of them has become non-endemic. There are no cases of EN in towns, although they are close to endemic villages. The first outbreak of the disease in the endemic areas of all affected countries occurred simultaneously in the early 1950s, although there are indications that sporadic cases were seen earlier. Ten years later, a high incidence of otherwise rare urothelial tumours was recorded, first in the endemic area of Bulgaria, and then of other countries. Although a number of more or less plausible hypotheses have been proposed, the origin of EN is still unknown.

The mycotoxin theory of the development of EN was postulated in the early 1970s, because of similar kidney lesions in pigs exposed to mycotoxin ochratoxin A (OTA) and humans suffering from EN. A number of field studies were performed, mostly in Bulgaria and Croatia, whose aim was to confirm or reject this theory.

In 1992 a number of cases of interstitial nephritis were recorded in young women in Belgium, and later in other European countries that were followed 
by end-stage renal disease (1). All patients followed the same slimming regimen with Chinese herbs that accidentally contained Aristolochia fangchi, a herb with a known nephrotoxic compound, aristolochic acid (AA) which causes the so called AA nephropathy (AAN). Histopathological similarities between kidney lesions in EN and AAN have recently resuscitated the old theory of the involvement of AA in EN.

This paper reviews the main research findings supporting or opposing either the OTA or AA theory of EN origin.

\section{EPIDEMIOLOGICAL FEATURES OF ENDEMIC NEPHROPATHY AND CHINESE HERBS NEPHROPATHY}

From the early 1950s when EN was recognised as a nosologic entity, its appearance in Croatia changed significantly. In 1957-1960 the average age of patients at death was 45.1 years, while in 1991-2002 it was 69.2 years $(2,3)$. Although this increased life expectancy, similar to that of the general population in the area, is probably owed to lower exposure to the toxic compound, there are still new cases of the disease, and it does not disappear (4).

EN occurs exclusively in rural population, even though the endemic areas are located near towns. It still has not been proved that chronic interstitial nephropathies of unknown aetiology seen in North Africa (Egypt and Tunis) are OTA-caused EN (57), because high concentrations of OTA may also be found in patients with severe kidney failure (8). Therefore, it seems that EN neither expands nor disappears from the endemic areas (9). This is opposite to AAN, which appeared as an epidemic in the urban population first in Belgium in 1991 and then in other European countries, and the USA (10, 12). The other difference is that EN is the disease of familial or environmental clustering, while AAN is not. The sex ratio in EN is approximately $1: 1$, while AAN is dominant in women because women attended slimming clinics (10).

It also seems that exposure duration is quite different between EN and AAN. EN does not occur in children, but the inhabitants that have left the endemic area after over a decade of residence there are also known to develop EN. Patients with AAN usually developed the disease after several years of treatment with Chinese herbs $(10,11)$. In some cases nephropathy was characterised by a rapid deterioration in renal function, with initial serum creatinine doubling within about three months.

The development of urinary tract malignancy is also much slower in EN than in AAN. In the Croatian endemic area, the appearance of carcinomas of the urinary system peaked ten years after the peak of endemic nephropathy (2). In another endemic area, the latency for malignancies ranged between 20 and 27 years, while in AAN urothelial tumours occurred within two to six years $(13,14)$.

\section{EXPOSURE TO OCHRATOXIN A AND ARISTOLOCHIC ACID IN THE ENDEMIC AREAS}

Due to the endemic character of EN and its exclusive occurrence in rural population, it is believed that the causative agent of EN should be a natural nephrotoxic and carcinogenic compound more frequently found in the endemic than in non-endemic areas. The long latency of EN in persons who had lived in the endemic areas for at least 10 years and moved, suggests that the causative agent is slow-acting and that exposure continued for many years.

Mycotoxin OTA is a natural compound with nephrotoxic and carcinogenic properties, and was extensively investigated as the possible cause of EN. This product of moulds from the genera Aspergillus and Penicillium was found in the food and feed in the endemic areas (15). In humans, OTA was first detected in the blood of residents of the Croatian endemic area (16). A ten-year follow-up of OTA blood concentrations showed that these residents were more frequently exposed to OTA than controls (17). This study was performed on samples collected in winter, but later studies showed that OTA exposure is the highest in the summer, which means that this ten-year follow up did not measure the peak exposure (18). In Bulgaria, 576 blood samples were collected in the endemic and non-endemic areas in 1984, 1986, 1989, and 1990. OTA was detected in all groups, but was more frequent in patients with $\mathrm{EN}$ and urinary tract tumours than in healthy subjects in the endemic and control areas (19). According to studies referred to here, residents of the endemic areas are more frequently exposed to OTA than other populations, but because of the high variability in OTA concentrations, mean blood OTA in patients with EN was not significantly 
higher than in controls. OTA has demonstrated its nephrotoxic properties in all laboratory animals, and there is no reason that it should not have the same effects in humans. OTA was found in food and feed all over the world (20), and low OTA concentrations were found in residents of countries where EN has not been identified so far (21). However, this finding does not discard mycotoxins as possible causes of EN, because there are other mycotoxins (such as citrinin, penicillic acid, and fumonisins) with nephrotoxic properties that may have a synergistic effect (22-26).

According to the AA theory, residents of the endemic areas suffering from EN are exposed to aristolochic acid from the seeds of Aristolochia clematitis (birthwort) contaminating the wheat. However, this exposure seems rather uncertain. The only paper dealing with this problem analysed a questionnaire about the presence of birthwort in the fields. Patients with verified EN remembered more frequently than healthy individuals that their fields were severely infested with birthwort (27). Both controls and EN patients declared that birthwort disappeared from their fields with more consistent use of herbicides and drainage that decreased humidity needed by the plant to grow. The authors did not mention that possible wheat contamination with birthwort 20 to 30 years ago does not entail higher exposure to AA, because at that time the usual practice was that farmers brought sacks of wheat to the mill where they immediately exchanged them for sacks of flour from wheat produced by other farmers. In other words, it is hard to establish real exposure to AA. Furthermore, birthwort is ubiquitous in Croatia, and there is no explanation why it should cause severe lesions only in the endemic area. Other authors also raised similar doubts. Thus, Long and Voice (28) say that in an EN area wheat is typically harvested in mid-summer when birthwort seeds are immature and contained within a large bulb that can easily be separated from the wheat grain. They also claim that combine harvesters have been used in some villages for many years and that these would easily screen off immature bulbs. For long many villages have had modern mills with sophisticated separation technologies. There is no evidence that bread is contaminated, or that AA exposure is consistent with the occurrence of EN (29). It should be stressed that so far no food analysis has demonstrated the presence of AA in food of the residents of the endemic areas.

\section{CLINICAL PICTURE OF EN AND AAN}

Since the early description of EN given by Radonić et al. (30), the clinical picture of this disease has not changed. EN is still a slow-progressing nephropathy of tubular type with the insidious onset. The initial appearance of interstitial fibrosis without affecting the glomerules and clinical presentation of mild hypertension is rather similar between EN and AAN. EN appears after non-specific signs such as fatigue, headache, loss of body weight, and pale skin. The effect on the tubules is characterized by a decrease in tubular transport that manifests itself in a very mild intermittent proteinuria and gradual rise of blood nitrogen (31). Mild anaemia either of aplastic or normochromic type is an early sign of EN, but blood pressure increases significantly only with greater impairment of the kidney function.

The main dermatological features of EN are yellow discoloration and dark stained palm lines that are not seen in AAN. In AAN anaemia is severe from the very beginning, and renal impairment may be slowed by steroid treatment (32).

It takes decades for EN to progress from the nonsymptomatic phase to the end-stage renal disease, while in AAN this progression is much faster (a few months or years) $(14,31)$. The other difference in clinical picture is that ureterohydronephrosis has not been reported in EN except in cases of urothelial tumors, while it is frequent in AAN (14). The single pathological difference between the two diseases lies in the more extensive and constant involvement of the columns of Bertin in AAN than in EN (1).

\section{OTA-DNA, AA-DNA ADDUCTS AND p53 MUTATIONS IN EN AND AAN}

It is well known that OTA and AA are carcinogenic in laboratory animals. Chemical carcinogens or their reactive metabolites bind covalently to the DNA molecule, forming thus DNA adducts. However, the presence of DNA adducts does not necessarily prove the involvement of a compound or its metabolite in the aetiology of cancer, but it does evidence exposure. OTA-DNA and AA-DNA adducts were found in the liver and kidney of experimental animals after respective OTA and AA treatment using the ${ }^{32} \mathrm{P}$-postlabelling method (33-35). Some authors have raised doubts about the origin of OTA-DNA adducts, suggesting 
that OTA and its metabolites can not form covalent bonds with DNA, and that adducts seen in the tissues of OTA-treated animals are the products of OTAmediated cytotoxicity $(36,37)$.

In several studies, these adducts were detected either simultaneously or separately in human kidney or in tumour tissues of the urinary tract. In a preliminary study of OTA-DNA and AA-DNA adducts in the kidney tissue of three Croatian patients with EN, both types of DNA adducts were found simultaneously in two samples, while no adducts were found in one (38).

OTA-DNA adducts were also found in eight tumour tissues of the kidney and urinary bladder of Bulgarian subjects that lived in a high-risk area for Balkan endemic nephropathy (39). In contrast, OTA-DNA adducts were not found in the tumour kidney tissues of French patients with AAN, analysed as controls. Instead, these and the tissues of surgically removed kidney, urothelial or tumor tissues of patients with AAN in Belgium contained only AA-DNA adducts (40). In a recently published paper OTA- and citrinin-DNA adducts were detected in the tumour kidney tissues of patients with EN from Croatia, Bulgaria, and Serbia, but AA-DNA adducts were not (41).

In contrast, there are authors reporting the presence of AA-DNA adducts in four renal cortex samples in patients with $E N$ and in three upper urinary tract tumour samples in patients from the endemic area of Croatia (42). These samples were not checked for the presence of OTA-DNA adducts.

Carcinogenesis is believed to be genetically determined and a consequence of the disrupted function of tumour suppressor genes or of the activation of oncogenes. The most studied mutations are changes in the p53 suppressor gene.

An analysis of p53 mutations revealed a statistically significant difference between mutation spectra in both the kidney and liver of AA-treated and control rats (34). In the liver and kidneys of AA-treated rats the predominant mutation was $\mathrm{A}: \mathrm{T} \rightarrow \mathrm{T}: \mathrm{A}$ transversion, whereas the main type of mutation in controls was $\mathrm{G}: \mathrm{C} \rightarrow \mathrm{A}: \mathrm{T}$ transition. Mutation $\mathrm{A}: \mathrm{T} \rightarrow \mathrm{T}: \mathrm{A}$ was found also in urothelial tumor cells of one patient with AAN (43). In 11 samples of transitional cell carcinomas in residents of endemic villages, 19 base substitutions were identified (42). All but one patient had at least one $\mathrm{A}: \mathrm{T} \rightarrow \mathrm{T}$ :A mutation, and this mutation accounted for $78 \%$ of all base substitutions detected. This high a percentage of p53 mutations was not found in a study of 90 blood samples of Bulgarian patients with EN; they were found in $10 \%$ of samples (44).

\section{CONCLUSIONS}

EN is a disease that occurs endemically in rural population, which indicates that a natural toxin should be involved in the aetiology of this disease. OTA and AA have nephrotoxic and carcinogen properties, and exposure to either of them may cause severe kidney lesions and tumours of the urothelial system. Until now, exposure to AA has been associated with the slimming regimen in young women in many highly developed countries, while EN has been the disease of the elderly rural population of both sexes. This suggests that the involvement of AA in the development of EN is not likely, which has also been concluded by Pfohl-Leszkowicz et al. (41).

\section{REFERENCES}

1. Cosyns JP. Aristolochic acid and "Chinese herbs nephropathy”. Drug Safety 2003;26:33-48.

2. Čeović $S$, Pleština R, Miletić-Medved M, Stavljenić A, Mitar J, Vukelić M. Epidemiological aspects of Balkan endemic nephropathy in typical focus in Yugoslavia. In: Castegnaro M, Pleština R, Dirheimer G, Chernozemsky IN, Bartsch H, editors. Mycotoxins, endemic nephropaty and urinary tract tumours. Lyon: International Agency for Research on Cancer; 1991. p. 5-10.

3. Miletić-Medved M, Domijan A-M, Peraica M. Recent data on endemic nephropathy and related urinary tumors. Wien Klin Wochenschr 2005;117:604-9.

4. Miletić-Medved M, Jelaković B, Bistrović D, Leko $\mathrm{N}$, Marić Z. Epidemiološke osobitosti endemske nefropatije u Hrvatskoj 2005. godine [Epidemiological characteristics of endemic nephropathy in Croatia in 2005, in Croatian]. Acta Med Croat 2007;61:141-8.

5. Maaroufi K, Achour A, Hammami M, El May M, Betbeder AM, Ellouz F, Creppy EE, Bacha H. Ochratoxin A in human blood in relation to nephropathy in Tunisia. Hum Exp Toxicol 1995;14:609-15.

6. Wafa EW, Yahya RS, Sobh MA, Eraky I, El-Baz M, El-Gayar HAM, Betbeder AM, Creppy EE. Human ochratoxicosis and nephropathy in Egypt: A preliminary study. Hum Exp Toxicol 1998;17:124-9.

7. Grosso F, Said S, Mabrouk I, Fremy JM, Castegnaro M, Jemmali $M$, Dragacci $S$. New data on the occurrence of ochratoxin $\mathrm{A}$ in human sera from patients affected or not by renal disease in Tunisia. Food Chem Toxicol 2003;41:1133-40.

8. Breitholtz-Emunelsson A, Minervini F, Hult K, Visconti A. Ochratoxin A in human serum samples collected in Southern Italy from healthy individuals and individuals 
suffering from different kidney disorders. Nat Toxins 1994;2:366-70.

9. Batuman V. Fifty years of Balkan Endemic nephropathy: daunting questions, elusive answers. Kindey Int 2006;69:644-6.

10. Vanherweghem JL, Depierreux M, Tielmans C, Abramowicz D, Dratwa M, Jadoul M, Richard C, Vandervelde D, Verbeelen D, Vanhaelen-Fastre $R$, Vanhaelen M. Rapidly progressive interstitial renal fibrosis in young women: Association with slimming regimen including Chinese herbs. Lancet 1993;341:387-91.

11. Vanherweghem JL. Misuse of herbal remedies: the case of an outbreak of terminal renal failure in Belgium (Chinese herbs nephropathy). J Altern Complement Med 1998;4:9-13.

12. Arlt VM, Stiborova M, Schmeiser HH. Aristolochic acid as a probable human cancer hazard in herbal remedies: a review. Mutagenesis 2002;17:265-77.

13. Ćukuranović R, Ignjatović $M$, Stefanović V. Urinary tract tumours and Balkan nephropathy in the south Morava river basin. Kidney Int 1991;40(Suppl. 34):80S-4S.

14. Cosyns JP, Jadoul M, Squifflet JP, Wese FX, van Ypersele de Strihou C. Urothelial lesions in Chineseherb nephropathy. Am J Kidney Dis 1999;33:10117.

15. Pavlović M, Pleština R, Krogh P. Ochratoxin A contamination of foodstuffs in an area with Balkan (endemic) nephropathy. Acta Pathol Microbiol Scand Sect B 1979;87:243-6.

16. Hult K, Pleština R, Habazin-Novak V, Radić B, Čeović S. Ochratoxina A in human blood and Balkan endemic nephropathy. Arch Toxicol 1982;51:313-21.

17. Radić B, Fuchs R, Peraica M, Lucić A. Ochratoxin A in human sera in the area with endemic nephropathy in Croatia. Toxicol Lett 1997;91:105-9.

18. Peraica M, Domijan AM, Matašin M, Lucić A, Radić B, Delaš F, Horvat M, Bosanac I, Balija M, Grgičević D. Variations of ochratoxin A concentration in the blood of healthy population in some Croatian cities. Arch Toxicol 2001;75:410-4.

19. Petkova-Bocharova T, Castegnaro M. Ochratoxin A in human blood in relation to Balkan endemic nephropathy and urinary system tumours in Bulgaria. In: Castegnaro M, Pleština R, Dirheimer G, Chernozemsky IN, Bartsch $\mathrm{H}$, editors. Mycotoxins, endemic nephropathy and urinary tract tumours. Lyon: International Agency for Research on Cancer; 1991. p. 135-43.

20. Speijers GJA, Van Egmond HP. Worldwide ochratoxin A levels in food and feeds. In: Creppy EE, Castegnaro $M$, Dirheimer G, editors. Human ochratoxicosis and its pathologies. Montrouge: John Libbey Eurotext Ltd., INSERM; 1993. p. 85-100.

21. Peraica M, Domijan A-M, Fuchs R, Lucić A, Radić B. The occurrence of ochratoxin $A$ in blood in general population of Croatia. Toxicol Lett 1999;110:105-12.
22. Petzinger E, Ziegler K. Ochratoxin A from a toxicological perspective. J Vet Pharmacol Therap 2000;23:91-8.

23. Ribar S, Mesarić M, Bauman M. High-performance liquid chromatographic determination of sphinganine and sphingosine in serum and urine of subjects from an endemic nephropathy area in Croatia. J Chromatogr B 2001;754:511-9.

24. Stoev SD, Stefanov M, Denev ST, Radić B, Domijan A-M, Peraica $M$. Experimental mycotoxicosis in chickens induced by ochratoxin A and penicillic acid and intervention with natural plant extracts. Vet Res Commun 2004;28:727-46.

25. Domijan A-M, Želježić D, Kopjar N, Peraica M. Standard and Fpg-modified comet assay in kidney cells of ochratoxin A- and fumonisin $\mathrm{B}_{1}$ - treated rats. Toxicology 2006;222:53-9.

26. Šegvić Klarić M, Pepeljnjak S, Domijan A-M, Petrik J. Lipid peroxidation and glutathione levels in porcine kidney PK15 cells after individual and combined treatment with fumonisin $B_{1}$, beauvericin and ochratoxin A. Basic Clin Pharmacol Toxicol 2007;100:157-64.

27. Hranjec T, Kovač A, Kos J, Mao W, Chen JJ, Grollman AP, Jelaković B. Endemic nephropathy: the case for chronic poisoning by Aristolochia. Croat Med J 2005;46:116-25.

28. Long DT, Voice TC. Role of the exposure analysis in solving the mystery of Balkan endemic nephropathy. Croat Med J 2007;48:300-11.

29. Voice TC, Long DT, Radovanović Z, Atkins JL, McElmurry S, Niagolova N, Dimitrov P, Petropolous EA, Ganev V. Critical evaluation of environmental exposure agents suspected in the etiology of Balkan endemic nephropathy. Int J Occup Environ Health 2006; 12:36976.

30. Radonić M, Radošević Z, Županić V. Endemic nephropathy in Yugoslavia. In: International Academy of Pathology, Monograph No. 6. The Kidney. Baltimore (USA): Williams and Wilkins Co.; 1966. p. 503-22.

31. Pleština R. Some features of Balkan endemic nephropathy. Food Chem Toxicol 1992;30:177-81.

32. Vanherweghem JL, Abramowicz D, Tielmans C, Depierreux M. Effects of steroids on the progression of renal failure in chronic interstitial renal fibrosis; a pilot study in Chinese herbs nephropathy. Am J Kidney Dis 1996;27:209-15.

33. Pfohl-Leszkowicz A, Chakor K, Creppy EE, Dirheimer G. DNA adduct formation in mice treated with ochratoxin A. IARC Sci Publ 1991;115:245-53.

34. Pfohl-Leszkowicz A, Grosse Y, Kane A, Creppy EE, Dirheimer G. Differential DNA adduct formation and disappearance in three mouse tissues after treatment with the mycotoxin ochratoxin A. Mutat Res 1993;289:265-73.

35. Schmeisser HH, Schoepe KB, Wiessler M. DNA adduct formation of aristolochic acid I and II in vitro and in vivo. Carcinogenesis 1988;9:297-303. 
36. Gautier J-C, Richoz J, Welti H, Markovic J, Gremaud E, Guengerich FP, Turesky RJ. Metabolism of ochratoxin A: absence of formation of genotoxic derivatives by human and rat enzymes. Chem Res Toxicol 2001;14:34-45.

37. Mally A, Zepnik H, Wanek P, Eder E, Dingley K, Ihmels H, Völker W, Dekant W. Ochratoxin A: lack of formation of covalent DNA adducts. Chem Res Toxicol 2004; 17:234-42.

38. Arlt VM, Ferlulga D, Stiborova M, Pfohl-Leszkowica, Vukelić M, Čeović S, Schmeiser HH, Cosyns JP. Is aristolochic acid a risk factor for Balkan endemic nephropathy-associated urothelial cancer? Int J Cancer 2002; 101:500-2.

39. Pfohl-Leszkowicz A, Grosse Y, Castegnaro M, PetkovaBocharova T, Nicolov IG, Chernozemsky IV, Bartsch H, Betbeder AM, Creppy EE, Dirheimer G. Similarity between ochratoxin $\mathrm{A}$ induced DNA adducts in mice and DNA adducts in urinary tract tumours in humans with Balkan endemic nephropathy. In: Scudamore K, editor. Occurrence and significance of mycotoxins. London: Central Science Laboratory; 1994. p. 23943.
40. Nortier JL, Munitz Martinez MC, Schmeiser HH, Arlt VM, Bieler CH, Petein M, Depierreux MF, De Pauw L, Abramowicz D, Vereerstraeten P, Vanherweghem JL. Urothelial carcinoma associated with the use of Chinese herb (Aristolochia fangchi). New Engl J Med 2000;342:1686-92.

41. Pfohl-Leszkowicz A, Tozlovanu M, Manderville R, Peraica $M$, Castegnaro M, Stefanovic V. New molecular and field evidence for the implication of mycotoxins but not aristolochic acid in human nephropathy and urinary tract tumor. Molec Nutr Food Res 2007;51:1131-46.

42. Grollman AP, Shibutani S, Moriya M, Miller F, Wu L, Moll U, Suzuki N, Fernandes A, Tosenquist T, Medverec Z, Jakovina K, Brdar B, Slade N, Turesky RJ, Goodenough AK, Rieger R, Vukelić M, Jelaković B. Aristolochic acid and the etiology of endemic (Balkan) nephropathy. PNAS 2007; 104:12129-34.

43. Schmeiser HH. Chemical and molecular basis of the toxicity of Aristolochia and plants containing pyrrolizidine alkoids. Toxicology 2007;240:147.

44. Krasteva ME, Georgieva EI. Germline p53 single-base changes associated with Balkan endemic nephropathy. Biochem Biophys Res Commun 2006;342:562-7. 


\section{Sažetak}

\section{MIKOTOKSINSKA I ARISTOLOHIČNA TEORIJA O UZROKU ENDEMSKE NEFROPATIJE}

Unatoč mnogim nastojanjima znanstvenika i epidemiologa, etiologija endemske nefropatije (EN) još nije razjašnjena. Postavljeno je više teorija o nastanku ove bolesti koja se javlja u ruralnom stanovništvu na geografski ograničenim područjima Bugarske, Bosne i Hercegovine, Hrvatske, Rumunjske i Srbije. Donedavno se najviše napora ulagalo u istraživanje povezanosti nastanka EN s izloženošću mikotoksinu okratoksinu A. Prikupljeni rezultati upućuju većim dijelom na opravdanost te pretpostavke. Zbog histoloških sličnosti bolesnika s EN i pacijentica koje boluju od nefropatije uzrokovane kineskim travama za koju je ustanovljeno da ju uzrokuje aristolohična kiselina (AA) postavljena je teorija da je AA uzročnik EN. Dosad nije potvrđeno da su stanovnici na lokalizacijama s endemskom nefropatijom izloženi povišenim koncentracijama AA u usporedbi s područjima bez te bolesti. Osim toga su i putovi izloženosti AA koji bi se mogli povezati s pojavom EN nejasni i nedokazani.

U ovom preglednom radu izneseni su rezultati najvažnijih istraživanja koja podupiru ili negiraju obje teorije, zajedno s nedostatcima svake od njih.

KLJUČNE RIJEČI: DNA-adukti, mikotoksini, nefropatija kineskih trava, okratoksin A, p53, tumori bubrega

\section{CORRESPONDING AUTHOR:}

Maja Peraica, MD, Ph.D.

Institute for Medical Research and Occupational Health

P. O. Box 291, HR-10001 Zagreb, Croatia

E-mail:mperaica@imi.hr 